\title{
Strategic management of an educational organization of a technical and professional orientation in the context of integration processes in the post-Soviet educational space
}

\author{
Almira Khozhanova ${ }^{1}$, Galina Zvezdina ${ }^{2 *}$, Marina Elagina ${ }^{2}$, Ekaterina Zvezdina ${ }^{2}$ \\ ${ }^{1}$ College of business and service, Semey, Republic of Kazakhstan \\ ${ }^{2}$ Don State Technical University, Faculty "Psychology, Pedagogy and Defectology", \\ 344000 Rostov-on-Don, Russian Federation
}

\begin{abstract}
The article presents the generalized experience of implementation of technology of strategic management of educational organization of technical and professional orientation in the post-Soviet space on the example of the Republic of Kazakhstan. The urgency of the studied problem in the conditions of convergence of educational policy of Russia and Kazakhstan is proved, the necessity of flexible response of educational systems of national States to the needs of the region and challenges of the modern digital economy is shown. Methodological bases of strategic management are considered, features of management of educational organizations in the conditions of transforming economy are shown. The scientific novelty of the article is the design of the development of an educational organization, improving its competitiveness with the help of strategic management technology on the example of the Municipal stateowned enterprise "College of business and service" Semey, Republic of Kazakhstan. The structure of strategic planning in the form of a technological process consisting of the implementation of interrelated actions from the moment of necessity in the development to the implementation of the strategy is presented.
\end{abstract}

Rapidly changing socio-economic conditions of a transitive society require new approaches to forecasting the needs of the economy and the social sphere in professionally trained personnel. The issue of leaving the labor market of unclaimed professions and the emergence of new ones that meet the needs of the digital economy becomes urgent, which requires the readiness of the education system for this situation. The education system is designed to respond in a timely manner to the new challenges of society, to quickly prepare competent personnel for the digital economy, capable of constant "preadaptation" (A. G. Asmolov).

Such a problem is relevant today for many educational systems throughout the postSoviet space. Solving a set of tasks at the national, regional and global levels urgently

\footnotetext{
${ }^{*}$ Corresponding author: galzvezdina@yandex.ru
} 
requires serious changes in the education system, making adjustments to the paradigm of its development in the XXI century.

It is becoming increasingly obvious that national education systems cannot develop outside of global processes and trends, outside of the demands of the world labor market, and therefore the role of integration processes in the field of education is increasing.

The most balanced and effective policy in this direction in the post-Soviet space is carried out by Kazakhstan [1].

In accordance with the State program of education development of the Republic of Kazakhstan for 2011-2020, the most important goal is to modernize the system of technical and vocational education in accordance with the needs of society and industrial and innovative development of the national economy, integration into the world educational space [2].

Between Russia and the Republic of Kazakhstan there are cooperation agreements with different purposes of unification, and subject to ratification of such agreements [3].

The convergence of educational systems occurs not only in time and space, but also in the field of educational policy, which determines the values, moral ideals and life priorities of consumers of educational services.

A fundamentally necessary feature of the educational policy of the States is a consistent focus on compliance with the principle of variability of education by creating "personal spaces" for independent decision-making by various participants in the educational process: students and teachers, professional and national communities, employers.

The search for building an effective educational organization, adequate to modern changing conditions, lead to the need to identify new approaches to management.

Since the early 1990s, strategic management, which is based on a qualitatively different approach to management decision-making, has been actively introduced into the economy. Strategic management means that the management process should be proactive, not reactive, that is, it is necessary to influence events in the external environment, and not just respond to them.

The problem of strategic development are well represented in foreign and domestic science, the highlights of which are studies of the following scientists: I. now, Ansoff, M. porter, F. Selznick, K. Andrews investigated the nature of the formation of strategies; G. Allison, R. Kauert, G. Simon, M. Hannan studied the methodology of the process of formation of strategy. The convergence of educational systems occurs not only in time and space, but also in the field of educational policy, which determines the values, moral ideals and life priorities of consumers of educational services.

A fundamentally necessary feature of the educational policy of the States is a consistent focus on compliance with the principle of variability of education by creating "personal spaces" for independent decision-making by various participants in the educational process: students and teachers, professional and national communities, employers.

The search for building an effective educational organization, adequate to modern changing conditions, lead to the need to identify new approaches to management.

Since the early 1990s, strategic management, which is based on a qualitatively different approach to management decision-making, has been actively introduced into the economy. Strategic management means that the management process should be proactive, not reactive, that is, it is necessary to influence events in the external environment, and not just respond to them.

The problem of strategic development are well represented in foreign and domestic science, the highlights of which are studies of the following scientists: I. now, Ansoff, M. porter, F. Selznick, K. Andrews investigated the nature of the formation of strategies; G. Allison, R. Kauert, G. Simon, M. Hannan studied the methodology of the process of formation of strategy. 
The founder of strategic management is considered to Be I. Ansoff, who considered strategic management as two complementary subsystems: the subsystem of analysis and strategy planning and the subsystem of strategy implementation.

Education as a social institution has its own peculiarities in functioning and management. According to researchers, the features of the strategic management of the educational system are determined by "its essential features, principles of operation, mission need execution of particular socially important functions in modern society and directions of development corresponding to the needs of society, the state and the individual in the long term, taking into account geographical, cultural, historical and resource potential of regions" [4].

The primary task of each educational organization is to create its own unique strategic development model. The strategic vision of the future of the organization, its activities is put forward today to the forefront. E. N. Knyazeva, revealing the features of modern management theory from the point of view of synergetics, notes that the current attitude in management is not just to predict the future, but also to create the desired future, to design the future, to direct the development of social systems and organizations in line with our preferred and feasible (in terms of the internal properties of social systems) development trends [5].

Modern management is the art of achieving goals through the use of labor, intelligence, motives of other people's behavior [6]. Strategic management-the process that determines the algorithm of actions of the organization for the development and implementation of the strategy [7].

Let's consider the possibilities of strategic management of educational organization of technical and professional orientation on the example of Municipal state enterprise "College of business and service" Semey, Republic of Kazakhstan.

The structure of strategic planning in the organization of education can be represented in the form of a technological process consisting of the implementation of interrelated actions from the moment of the need to develop to implement the strategy.

The first stage in the design of the strategic development plan is the development of the mission and vision, the main task of which is the provision of quality education. The mission of the organization should reflect the interests of all stakeholders of the organization, which are: the state; society; clients, students, parents; engineering and teaching staff and administrative staff; employees; social and business partners.

The organization forms its vision immediately after the analytical stage. The formed longterm vision will give an opportunity to avoid erroneous decisions and ensure consistency of the organization's policy with the state policy of education of the Republic of Kazakhstan.

Analyzing the immediate environment, the organization studies the industry in which it works in the following areas: social partners, students (parents / officials), competitors.

At the second stage, development goals and target indicators are developed and defined. Indicative planning in the field of education of Kazakhstan is Advisory in determining the indicators of development at the micro level.

Goal - a specific result achieved by the end of the planning period, that is, a target indicator that will determine the effectiveness of the goal.

Formed goals must meet a number of requirements: brevity and clarity, measurability, relevance, achievability, consistency, the possibility of adjustment.

The practice of strategic management does not recommend setting a large number of goals, the optimal number is four or five goals.

Target indicators should be comparable in dynamics, achievable and measurable, give a comprehensive description of activities, flexibly adjusted.

Each organization sets itself a certain goal, which is very often formalized in the mission of this organization, which is in a given time period in some current position, from which it can not immediately go to the desired state determined by the mission. 
To assess the effectiveness of the mission, goals and objectives, a SWOT analysis is carried out to determine the strengths and weaknesses of the organization, its opportunities in the educational market and threats to the environment.

The information obtained during the analysis of internal, external factors and the immediate environment of the organization is the result of strategic analysis. The internal environment determines the potential of the educational institution in the field of quality of educational services and should respond flexibly to changes in the external environment.

The process of agreeing and approving a strategic development plan should begin with the establishment of a working group. In order to get the plan from the corporate positions, the group must include the head of the organization of education, his deputies, heads of departments (heads of departments, head of personnel, chief accountant and other specialists).

Without an in-depth economic analysis of the organization's performance over the past years and without reasonable future forecasts for the future, without identifying shortcomings and errors, it is impossible to develop a strategic plan, choose an effective, correct version of the management decision.

In order to develop a strategic plan for the development Of the College of business and service of Semey, the Department of education of the East Kazakhstan region analyzed the current state of economic development.

Analysis of the financial and economic condition of the College of business and service showed that this area of operation of the organization requires significant improvements and changes, including finding new extra-budgetary funds to cover the basic expenses of the organization.

The reorganization of the College was based on the principle of regionalization and diversity. The College is focused on the transition to the mode of innovative development, which involves the renewal of the system of providing educational services in the educational institution, which involves changes in the structure of the College management, the content of education and teaching support. Updating the content of education is necessary to enhance the flexibility and mobility of College graduates in the industrial and social environment and expand employment opportunities in the specialty.

The achievement of the goals and objectives of the strategic program will be carried out through the implementation of interrelated in terms of time, resources and sources of financial support activities that will be implemented in several areas.

To prepare qualified professionals in the College must include the following activities: monitoring the staffing needs of the enterprises of city and region in the context of professions; the establishment of a centre for monitoring and evaluation of education quality; the establishment of a competence center for the Worldskills competence; organization and conducting of demonstration examinations on business qualifications; organization and conduct on the basis of the competence center regional championship of professional skills Worldskills.

In order to increase the personnel potential, it is necessary to provide the following list of activities: organization of professional development and training of teachers of special disciplines and masters of industrial training, including Worldskills standards; training of WorldSkills championship experts from among teachers and masters of industrial training.

To create optimal conditions for the training of qualified personnel, it is necessary to provide:

- re-equipment of the material and technical base of classrooms and laboratories, including in accordance with the infrastructure sheets of the WorldSkills championship;

- organization of training together with employers, renewal of social partnership, involvement of employers in updating the material and technical base of the College, as well as in the management of the College. 
Thus, the main directions of the strategic program of development of the College of business and service were determined:

- marketing management and evaluation of the quality of educational services;

- improving social partnership;

- optimization of the organizational structure of the College management;

- development of human resources of the College;

- improvement of the material and technical base of the College and educational and methodological support of the educational process.

The development of the strategic plan for the development of the College of business and service for 2020-2025 was started with the formulation of the purpose of the organizations of technical and vocational education, which should reflect the needs of the main stakeholders-participants of the educational process, to be met, and set out the directions of real achievement of these needs.

The main stakeholders of organizations of technical and professional orientation are citizens of the Republic of Kazakhstan, foreign citizens and stateless persons with basic secondary (basic General), General secondary (secondary General), technical and vocational (primary vocational and secondary vocational), post-secondary, higher (higher professional) education [8].

A distinctive feature of this market segment is the desire to obtain high qualifications for a short period of study (in comparison with the University) and on-the-job.

This market segment is also characterized by an average family income and a low level of educational training, which does not allow its representatives to enter higher education institutions.

The next stakeholders interested in the activities and development of technical and professional educational institutions are representatives of the labor markets - enterprises, organizations that serve as consumers of graduates with technical professional education. This is due to the fact that for small companies that have limited financial and material resources and do not have significant volumes of products or services, the average level of qualification of specialists is sufficient. The labor costs of such specialists are much lower than those with higher education. Diversification taking place in the field of technical and professional education changes the attitude of these stakeholders to the specialists of technical and vocational education, as the level of training today competes with many higher educational institutions, focused on obtaining practical skills, adapted to a single tariffqualification directory of jobs and professions, the national qualifications framework and professional standards in various fields of knowledge.

The main advantage of technical and vocational education in comparison with higher education is the standard period of study - an average of three years.

The next stakeholder is the society, as it is interested in the education of citizens, especially since the regional and Republican budgets today allow funding organizations of technical and professional orientation.

The second direction of the activities of the College of business and the service is continuing professional education, and implementation of the program "Development of productive employment and mass entrepreneurship for 2017-2021," together with the employment centers, the Families and districts by organizing short-term courses of professional education in demand on the labour market professions in different directions.

So, we can conclude that the distinctive characteristics of the College of business and service are quite a complete number of areas of educational activity and a wide range of educational services. The branch organization of education is replaced by a regional multidisciplinary organization that trains qualified personnel for implementation in different fields of activity. 
The need to modernize the management of organizations of technical and professional orientation in the Republic of Kazakhstan is determined by increasing the competitiveness of personnel in the labor market and the possibility of integration into a single post-Soviet educational space.

\section{References}

1. A.P. Kutrovsky, Regional studies, 4 (2014)

2. The state program of education development of the Republic of Kazakhstan for 20112020, approved by the decree of the President of the Republic of Kazakhstan dated December 7, 2010 № 1118. http://www.zakon.kz/141156-zakon-respubliki-kazakhstan-ot-27.html

3. N.N. Naydenova, Modern pedagogy, 11 (2015)

4. L.L. Portyanskaya, Bulletin of Kostroma state University. N.A. Nekrasova, 4 (2009)

5. E.N. Knyazeva, Synergistic design world. http://spkurdyumov.narod.ru/KnyazevaElena.htm

6. S.Yu. Buntovsky, E.O. Zhilenko, Integration of Sciences, 4 (2017)

7. P. Drucker, Management challenges for the twenty-first century (Williams, Moscow, 2000)

8. Standard of the state service "acceptance of documents in the organization of technical and professional, post-secondary education". https://iqaa.kz/turinskij-protsess/turinskijprotsess-v-kazakhstane 